\title{
Astakhova L. \\ INFORMATION AND PSYCHOLOGICAL IMPERATIVE OF SAFETY CULTURE OF A SUBJECT
}

У статті визначено поняття культури інформачійно-психологічної безпеки. На основі виявлених особливостей виділено $і ̈$ «захисний» $i$ «наступальний» рівні та відповідні їм стратегї забезпечення. Обгрунтований імператив обліку цих рівнів і стратегій в методиках ідентифікації i оцінки ризиків безпеки організації. Наведено результати соціологічного опитування жителів російського міста, який виявив недостатній рівень культури їх безпеки.

Ключові слова: культура безпеки, культура інформаційно-психологічної безпеки, інформаційнопсихологічні кадрові уразливості безпеки, оцінка вразливостей.

\section{Problem}

Inadequate attention is paid to the constituent part of safety culture that is information and psychological safety of a subject.

\section{Analysis of research and publications}

In the last decade the scientists of different fields of study in various countries are concerned about the problems of safety culture [1-3]. There are a lot of papers in which the notion and structure [4,5], levels and parameters [10], the processes of safety culture analysis [11] are determined. Specially developed techniques for risks analysis of safety are of a great attention. Thus, the technique of social and technical risk analysis (SoTeRiA) integrates models of risks of technical systems with social risks which include the culture of safety [13]. Cognitive strategies of personnel errors detection are developed [12]. However, unfortunately in the mentioned and other research inadequate attention is paid to the constituent part of safety culture that is information and psychological safety of a subject.

\section{Purpose of article}

The purpose of this paper is to develop strategies for improving safety culture of an organisation's staff taking into account the level of culture of their information and psychological safety.

\section{The main material}

Apart from natural habitats of a man there is information media of his inhabitation the value of which is rapidly increasing by further information civilization formation. This media greatly affects the person influencing his development and his personality activity, his spiritual and psychological as well as mentality development, his state of mind and health. One can mention several unfavourable factors which lead to the threats to information and psychological safety.

Basic factor is information explosion or burst-type increase of all types of traditional printed information as well as electronic information resources. Quantitative growth of information has led to the fact that a person can't perceive, understand and systematize even those sources of information which are necessary for professional occupation to make managerial, technical, scientific and other decisions. This factor has given rise to oversaturation of information media. A great amount of information less regard to its qualitative characteristics negatively affects personality.

One more negative factor which influences the mind of a modern man and makes him vulnerable from the viewpoint of safety is considerable pollution of information media. The authors who study the qualitative part of information flows consider that there can't be a lot of information and information stress isn't evoked by abundance of information but a great number of lowquality information and inability of a person to select and transform information to intelligent product that is knowledge critically.

The third negative factor influencing information and psychological safety violation is a broad distribution of the ways to manage people's behaviour, manipulations, information and psychological influence on individual and mass consciousness. The experts differentiate several levels of manipulative techniques application. The first level is an organized influence and psychological operations implemented during interstate policy. The second level of information and psychological influence of a manipulative type is the use of different means and techniques in political in-fighting, economic competition and company activity which are in the sate of conflict confrontation. Finally the third level includes manipulation of people in the process of interpersonal interaction. Economical peculiarities of the market of contemporary Russia and post-Soviet space make fundamental changes in behaviour of a great part of people the majority of which is not prepared for hard rules of surviving in terms of individualism either psychologically or morally [2].

Negative information influence at low stability threshold and inability to neutralize them reduces the capability of a man to behave properly in standard situations, makes him vulnerable in abnormal situations, and contributes to the increase of numbers of abuse of safety guidelines, human errors. 
The notion of culture of information and psychological safety is the part of a general notion of culture of information safety. Based on assignment conceptions of information safety and culture we have formulated the definition of culture of information safety. Culture of information safety is a method of organization and development of a human activity in information space which provides qualitative information media (the quality of information used, protection of the subjects from negative information effects) (information and psychological safety) and the degree of protection of the information (information security). Finally with the help of this method having dual structure complete satisfaction of information requirements of the subjects can be achieved.

To define the notion of the culture of information and psychological safety we use methodology of a pragmatic approach which is the analysis of basic components of activity such as the purpose, the object and the subject, processes, methods and the result.

The purpose of activity to provide information and psychological safety of a subject thus the result of the activity is the degree of owns protection as well as the others from poor information and negative information effects. The objects in terms of information interaction with nature are the subjects of information interaction. In this case the society and the state can be the objects but the processes and means of provision of their information protection are different.

To mark the conditions for information interaction we shall use the classification of communication situations developed by G. V. Grachev [1]. G. V. Grachev divides these conditions for interaction into three groups speaking about the communication situations in which information and psychological influence is made on the person. These groups are interpersonal communication situations, contact communication situations, mass communication situations. One of the processes of the provision is the recognition of a person as a subject of provision of protection from information impact. The extension of the degree of protection from negative information impact as the result of the activity suggests the threat and counteraction [7, p. 20]. Therefore, the processes of provision of a subject protection state are the following: the exposure of threat of information and psychological safety and counteraction by means of the use of knowledge and skills (mental formations) in the sphere of information and psychological safety, memory, criticality of reasoning (mental processes); empathy and reflection (social and psychological) (methods of cognition, appreciation of the world and oneself as a part of the world) by a subject.

Taking the notion of culture as basis for specific method of a human activity and the notion of information and psychological safety as the state of protection of subjects of information interaction from poor information and negative information effects we shall formulate the notion of culture of information and psychological safety.

Culture of information and psychological safety is a strategic component of safety culture in the form of the range of basic structural components (motivation, cognitive, technologic, creative), defining the method of organization and development of vital function at which the subject of information interaction is considered to be both the object and the subject of information and psychological safety, is able to detect the threat of his own safety as well as the safety of the recipient, knows the techniques of protection from them as well as capable to forecast the degree of safe influence of is positive and negative information effects on the recipient.

Academic novelty of a given definition of culture of information and psychological safety is in the use of methodology of a pragmatic approach to it. This approach makes it possible to differentiate two peculiar features of this phenomenon. The first feature is connected with the strategic role of culture of information and psychological safety in the structure of safety. Low level of culture revealed in information and psychological vulnerability of a subject is vulnerability of not only information but other types of safety of a subject such as the society, the company and the personality. Thus, a man, responsible for radio active, fire, antiterrorist, economic and other types of safety can't be an easy man believing negative message from the source without checking it by alternative source.

The second feature is the necessity of self-awareness of the fact that the subject is both the object and the subject of information and psychological effects simultaneously by the subject of information interaction. As the passive object of effects a man must be capable of revealing the threat of his information and psychological safety, using the techniques of protection from them. As an active subject of effects he must have motivation to transform information media safely, get rid of motivated and spontaneous negative information effects on other subjects of interaction at work, at home and other public places.

It is the second feature that is the source of exposure of two parameters of level of information and psychological safety of a subject: they are defensive and offensive one. Defensive parameter is characterized by the needs of the subject in the protection from negative information effects and the level of the use of protection techniques from them; offensive parameter is the requirement to follow humanistic principles of communication on the basis of value system as well as to be able to forecast the results of his information interaction with other subjects.

The existence of the key elements (motivation and technological) should be assessed in the process of analysis of vulnerability of the level of his information and psychological safety in the structure of information and psychological qualities of an employee, and finally his professional suitability to fulfill the functions of safety.

To identify and develop defensive and offensive properties of a person a set of special techniques and methods can be used. To master defensive strategy of behaviour the technique of opposition to influence by E. V. Sidorenko [6] and method of protection from invisible management, manipulation by V. P. Sheynov [9] are given. Mastering the offensive strategy should be done on the basis of hermeneutical approach to the analysis of manipulation analysis by E. L. Dotsenko [3], approach of strategic interaction in the situations of mental violence by S. Khassen [8] and others.

Unfortunately in practice the problems of provision of information and psychological safety of population are not paid attention to. For example, the Ural region is traditionally basis for industry and military technology of Russia. That is why the provision of information and psychological safety in the Ural federal district has true specific character and is required special attention. Detected problems of information and psychological safety of the 
region, the necessity of decision are proved by the results of opinion poll of the population of Chelyabinsk, made to reveal the state of information safety of the citizens.

896 respondents over 18 have been interviewed. The structure of the selection totality corresponds to the structure of general totality. The citizens of all districts of the city living in different streets and houses of a different type have been interviewed.

The first unit of questions is connected with the exposure of idea of the citizens of the Chelyabinsk region of information safety and their threat, sources of the treat. The analysis of the results of research shows that only $29 \%$ of respondents consider the threats of information and psychological safety in the region to be the most dangerous; however at communication with unfamiliar people only $29 \%$ of respondents are open and are ready to learn a man and reach mutual understanding; $48 \%$ of respondents are careful and try to keep everything under control learning true goals; $23 \%$ of respondents keep to ritual type of communication. We suppose that low level of danger of information and psychological threat is insufficiently reflected on by the respondents. $37 \%$ of respondents point that they are the objects of negative information and psychological effects and manipulation. Basically these effects come from distributers of different services and products (this is pointed at by $46 \%$ of respondents) and from separate persons (33\%), mass media $(32 \%)$. There is a great deal of those who consider the source of negative information and psychological effects and manipulation to be destructive religious services $(23 \%)$. The problems of information and psychological safety are proved by the fact that only $21 \%$ of respondents feel safety; $48 \%$ answer negatively. Most part of respondents (30\%) hasn't think of this question yet. The results of the analysis of the unit of questions prove narrow stereotyped image of information safety, insecurity of regional information space that pose a threat to constitutional rights of the citizens of a subject in information sphere.

The second unit of questions is connected with the methods and of information safety provisions. Being in a difficult real life situation means the citizens of Chelyabinsk address to their parents and friends (62\% and $40 \%$ correspondingly), quite rarely they address to the police and social safety service $(13 \%$ and $8 \%$ correspondingly), sometimes to their colleagues (9\%) and to the court $(7 \%)$. In the citizen's opinion they should provide information security themselves (37\% of respondents), $24 \%$ of respondents consider the Government of the Russian Federation to be responsible for this problem, $16 \%$ of respondents assume that it is the responsibility of the President of the Russian Federation, $15 \%$ of respondents mention Federal Security Service of Russia. However despite of assurance in the necessity of self-protection from negative influence of information the respondents have no idea of how to do it. Thus, the question on the influence of information on a man is given the answer that a great amount of information needs to be checked and thoroughly selected by $36 \%$ of respondents. This low \% of the city citizens understands the threat from information and the necessity of development of critical perception of information. Without knowing the techniques for information self-security $76 \%$ of the citizens of Chelyabinsk have no idea of the measures taken by the authorities of the Chelyabinsk region to provide information safety of population. The citizens of Chelyabinsk do not know anything about the regional policy of information safety and try to secure themselves without any help from the government authorities. This proves that there are problems of information provision of information safety policy not only in the Chelyabinsk region but in Russia as a whole as well. It is evident that the culture of information and psychological safety of the citizens of the region is poor.

It is clear that even brief overview of the poll results connected with the exposure of some parameters of the level of information safety proves insecurity of information media of the region and low level of culture of information and psychological safety of the citizens to exercise their own constitutional rights in information sphere; insufficient level of information provision of regional policy of security.

The solution to the problem of provision of information and psychological safety should be system like and is considered in the context of formation and development of security culture. One should pay much attention to different levels: 1) regulatory which means the creation of regulatory basis for a normal problem by the state authorities; 2) organization and institutional based on the coordinated actions of different social institutions; and 3) cultural and personal, which requires constant self-education, self-education of a person, formation of personal qualities which are necessary for provision of information self-protection and information and communicative offense. In every organization development and documentation of methodology for identification and analysis of safety vulnerability are required. Identification, assessment and methods for neutralization of information and psychological personnel vulnerability and risks for safety for security of these organizations should have leading role in this methodology.

\section{Conclusions}

The underestimation of culture of information and psychological safety of the subject is observed not only in safety culture theory, but also in Russian practice. The culture of information and psychological safety is an integral part of safety culture of the subject. In the structure of culture of information and psychological safety, the defensive and offensive levels are stated and corresponding strategies of behavior are substantiated. These levels and strategies need to be taken into account in the process of elaboration of methods for the identification and assessment of safety risks of the organization, as well as the evaluation of the level of safety culture of the organization's personnel.

Scientific novelty of the research is to specify the notion of culture of information and psychological safety as an obligatory part of the culture of safety, in defining its structure and content. Theoretical significance of the obtained results lies in expanding the theoretical ideas of culture of safety by introducing the concept of culture of information and psychological safety to scientific usage and its substantiation. The practical significance of the research lies in the fact that training personnel in defensive and offensive strategies of behavior can provide a basis for raising the level of their safety culture, and, therefore, the successful functioning of the organization under the conditions of the information society. 


\section{Лiтература}

1. Грачев, Г. В. Личность и общество: информационно-психологическая безопасность и психологическая защита [Текст] / Г. В. Грачев. - Волгоград: Издатель, 2004. - 336 с.

2. Грачев, Г. Манипулирование личностью: организация, способы и технологии информационно-психологического воздействия [Электронный ресурс] / Г. Грачев, И. Мельник. Режим доступа: \www/ URL: http://www.philosophy.ru/iphras/ library/manipul.html.

3. Доценко, Е. Л. Психология манипуляции: феномены, механизмы и защита [Текст] / Е. Л. Доценко. - СПб. : Речь, 2004. - 304 c

4. Мошкин, В. Н. Воспитание культуры безопасности школьников [Текст] : дис. докт. пед. наук: 13.00.01. - Барнаул, 2004. -316 c.

5. Немкова, И. Н. Формирование культуры безопасности жизнедеятельности студентов в процессе профессиональной подготовки в вузе [Текст] : дис. канд. пед. наук: 13.00.08. Тамбов, 2005. - 238 с.

6. Сидоренко, Е. В. Психология влияния и противостояния влиянию [Текст] / Е. В. Сидоренко. - СПб. : Речь 2002. -256 c.

7. Тер-Акопов, А. А. Безопасность человека: Социальные и правовые основы [Текст] / А. А. Тер-Акопов. - М. : Норма, 2005. - 272 с

8. Хассен, С. Освобождение от психологического насилия [Текст] / С. Хассен. - СПб. : Прайм-Еврознак, 2002. - 400 с.

9. Шейнов, В. П. Психология влияния: скрытое управление, манипулирование и защита от них [Текст] / В. П. Шейнов. - М. : Ось-89, 2008. - 720 с

10. Choudhry, R. M. The nature of safety culture: A survey of the state-of-the-art / R. M. Choudhry, D. A. Fang, S. B. Mohamed // Safety Science. - Volume 45, Issue 10, December 2007. Pp. 993-1012.

11. Flin, R. Measuring safety culture in healthcare: A case for accurate diagnosis / R. Flin // Safety Science. - Volume 45, Issue 6, July 2007. - Pp. 653-667.
12. Kontogiannis, T. A proactive approach to human error detection and identification in aviation and air traffic control / T. Kontogiannis, S. Malakis // Safety Science. - Volume 47, Issue 5, May 2009. - Pp. 693-706.

13. Mohaghegh, Z. Incorporating organizational factors into probabilistic risk assessment of complex socio-technical systems: Principles and theoretical foundations / Z. Mohaghegh, A. Mosleh // Safety Science. - Volume 47, Issue 8, October 2009. - Pp. 1139-1158.

\section{ИНФОРМАЦИОННО-ПСИХОЛОГИЧЕСКИЙ ИМПЕРАТИВ КУЛЬТУРЫ} БЕЗОПАСНОСТИ СУБЪЕКТА

В статье определено понятие культуры информационнопсихологической безопасности. На основе выявленных особенностей выделены ее «защитный» и «наступательный» уровни и соответствующие им стратегии обеспечения. Обоснован императив учета этих уровней и стратегий в методиках идентификации и оценки рисков безопасности организации. Приведены результаты социологического опроса жителей российского города, выявившего недостаточный уровень культуры их безопасности.

Ключевые слова: культура безопасности, культура информационно-психологической безопасности, информационнопсихологические кадровые уязвимости безопасности, оценка уязвимостей.

Астахова Людмила Вікторівна, професор кафедри безпеки інформаційних систем, Південно-Уральський державний універcumem, Pocis, e-mail: lvastachova@mail.ru.

Астахова Людмила Викторовна, профессор кафедры безопасности информационных систем, Южно-Уральский государственный университет, Россия.

Astakhova Lyudmila, South Ural State University, Russia, e-mail: lvastachova@mail.ru

Басова Ю. 0. ДОСЛІДЖЕННЯ СВІТЛОВОї ВІДДАЧІ
КОМПАКТНИХ ЛЮМІНЕСЦЕТНИХ
ЛАМП ЗАЛЕЖНО ВІД ІХХ КОНСТРУКЦІї

Робота присвячена дослідженню світлової віддачі компактних люмінесцентних ламп залежно від кількості каналів лампи та відстані між ними. Для теоретичного аналізу використовувалася модель, яка враховує багаторазові відбивання між паралельно розміщеними каналами. Показано, що світлова віддача зменшується із збільшенням каналів $і$ зменшенням відстані між ними. Розрахункові результати підтверджені експериментально.

Ключові слова: компактна люмінесцентна лампа, світлова віддача, К.К.Д., конструкція лампи.

Для розрахунку К.К.Д. багатоканальної лампи необхідно враховувати багаторазові відбивання. Така необхідність викликана значним коефіцієнтом поглинання світла поверхнею колби лампи (до 0,3). Саме багаторазові відбивання між паралельно розміщеними каналами лампи і призводять до втрат світлового потоку. Багаторазові відбивання можна визначити із виразу:

$$
\chi=\frac{1}{1-\rho_{\pi}(1-f)},
$$

де $\rho_{\text {л }}-$ коефіцієнт відбивання поверхні лампи $(\rho \approx 0,7)$; $(1-f)$ - частина світлового потоку каналу лампи, яка падає на сусідні канали.

$$
(1-f)=\frac{2 \phi}{\pi}=\frac{2 \arcsin (d / 2 l)}{\pi},
$$

де $f$ - коефіцієнт використання світлового потоку.

Коефіцієнт використання світлового потоку $f=$ $=(1-2 \phi) / \pi$ визначається відношенням плоских кутів, так як лампа випромінює і відбиває світловий потік 